\title{
Evaluation of the efficacy of commercial sanitizers against adhered and planktonic cells of Listeria monocytogenes and Salmonella spp.
}

\author{
Avaliação da eficiência de desinfetantes comerciais contra células aderidas e planctônicas de
} Listeria monocytogenes e Salmonella spp.

Julia CARBALLO ${ }^{1 *}$, Ana-Belén ARAÚJO ${ }^{1}$

\begin{abstract}
Antimicrobial activities of two commercial disinfectants, alone or combined with heat, against three Salmonella strains and three Listeria monocytogenes strains were studied. The efficacy of disinfectants against planktonic bacteria and bacteria attached to three food contact industrial surfaces (stainless steel, polytetraflourethylene, and rubber) was investigated. The tests were conducted using the sanitizer (quaternary ammonium compounds, and alquyldiethylenediamineglycine and di-alquyldiamineethylglycine) concentrations recommended by the manufacturers, and concentrations twice and four times higher than those values. The recommended concentrations were not effective to kill bacteria, especially when they were attached to surfaces. Concentrations of disinfectants twice and four times higher than those recommended were needed to fully eliminate planktonic bacteria. These same sanitizer concentrations were not sufficient to remove attached bacteria. To remove them from the surfaces, a treatment with recommended concentrations in combination with heat was needed. Our results indicate that these two pathogenic bacteria could survive common sanitation programs used in the food industry.

Keywords: bacterial attachment; food contact surface; disinfection; sanitizer.
\end{abstract}

\section{Resumo}

Neste estudo, foi avaliada a atividade antimicrobiana de dois desinfetantes comerciais, individualmente e combinados com calor, contra três estirpes de Salmonella e três de Listeria monocytogenes. A eficácia dos desinfetantes foi investigada contra bactérias em suspensão e contra bactérias aderidas a três superfícies de contacto comuns na indústria de alimentos (aço inoxidável, politetrafluoretileno e borracha). Os ensaios foram realizados com base nas concentrações de desinfetantes recomendadas pelos fabricantes e em concentração dupla e quádrupla. As concentrações recomendadas não foram efetivas contra as bactérias, especialmente quando estas estavam aderidas às superfícies. Foi necessário o dobro ou o quádruplo da concentração recomendada de desinfetante para eliminar as bactérias em suspensão. Essas mesmas concentrações não foram suficientes para eliminar as bactérias aderidas. De forma a erradicá-las da superfície, foi necessário um tratamento com a concentração recomendada em combinação com calor. Os resultados indicaram que essas estirpes patogênicas podem sobreviver a tratamentos de desinfecção habitualmente aplicados na indústria alimentícia.

Palavras-chave: aderência bacteriana; superfície de contacto com alimentos; desinfecção; desinfectante.

\section{Introduction}

Cross contamination of food products due to contact with food processing surfaces might be a major problem in the food industry (KUSUMANINGRUM et al., 2003a). The persistence of bacteria on surfaces has been suggested to relate to their attachment to food contact materials (GRAVESEN; LEKKAS; KNØCHEL, 2005; VALERIANO et al., 2012). Pathogenic bacteria may remain on equipment surfaces increasing the risks of transmission of diseases (SILVA et al., 2008; BELESSI et al., 2011).

Salmonella spp. and Listeria monocytogenes are examples of pathogenic bacteria implicated in outbreaks associated with the ingestion of contaminated food (LO FO WONG et al., 2002; GANDHI; CHIKINDAS, 2007). It has been proved that Salmonella Typhimurium can survive up to four weeks on dry surfaces in high-enough populations to be transferred to foods immediately on contact (DAWSON et al., 2007). It has also been found that L. monocytogenes can be transferred from foods to surfaces (RODRIGUEZ; AUTIO; McLANDSBOROUGH, 2007) and reciprocally (RODRIGUEZ; McLANDSBOROUGH, 2007). Indeed, it has been shown that these bacteria are able to attach to food contact surfaces (SINDE; CARBALLO, 2000; MAI et al., 2006; OLIVEIRA et al., 2006).

Research in this area has indicated that adherent microorganisms may be much more resistant to sanitizing compounds than planktonic cells (JOSEPH et al., 2001; KUSUMANINGRUM et al., 2003b; ALI et al., 2006).

The efficacy of the cleaning and disinfection operations of surfaces in the food industry depends on the design and type of surfaces, as well as on the procedures and products used. The outcome of these operations is limited by the ability of bacteria

\section{Received 23/11/2010}

Accepted 21/6/2012 (005146)

1 Área de Microbioloxía, Departamento de Bioloxía Funcional e Ciencias da Saúde, Facultade de Ciencias, Universidade de Vigo, Campus de Ourense, As Lagoas, 32004,

Ourense, Spain, e-mail: carballo@uvigo.es

${ }^{*}$ Corresponding autor 
to attach to surfaces and, eventually, to form biofilms (JENSEN; LAMMERT, 2003). In fact, it has been proved that Salmonella and L. monocytogenes cells are able to attach to different solid surfaces (SINDE; CARBALLO, 2000; BERESFORD; ANDREW; SHARMA, 2001; RAMESH et al., 2002) and they are present in food industrial environments (LO FO WONG et al., 2002; KATHARIOU, 2002).

Sanitizer efficacy is generally determined with microorganisms cultured under ideal conditions (MOORMAN et al., 2005). However, there is a lack of information on sanitizer efficacy against attached microorganisms in conditions resembling those encountered in the food industry (HOLAH et al., 1998; PALMER; FLINT; BROOKS, 2007; CERF; CARPENTIER; SANDERS, 2010).

The objective of this research was to determine the efficacy of two commercial sanitizers, alone or in combination with heat, against strains of Gram-negative (Salmonella spp.) and Grampositive (Listeria monocytogenes) pathogenic bacteria attached to food contact surfaces. Gram-negative and Gram-positive bacteria were chosen as models for this study because both types of bacteria can be found in surfaces of the food industry.

\section{Materials and methods}

\subsection{Bacterial strains, growth conditions, and suspensions obtainment}

Three strains of Salmonella (ES3, ES9 and ES20) and three strains of L. monocytogenes (ES15, ES24 and ES25) were used in this study. Bacterial strains were isolated in the course of routine food testing in the Food Control Services (Consellería de Sanidade) of Galicia (Spain). Salmonella strains were isolated from chicken liver, fresh sausages, and hamburgers, respectively. L. monocytogenes strains were isolated from frozen hake, cheese, and meat, respectively (SINDE; CARBALLO, 2000).

The strains were stored in skim milk (Fluka, Madrid, Spain) at $-20^{\circ} \mathrm{C}$. During the experiments, the strains were maintained on Trypticase Soy Agar (TSA, Cultimed, Madrid, Spain) at $4{ }^{\circ} \mathrm{C}$.

Overnight cultures in Trypticase Soy Broth (TSB, Cultimed) $\left(37^{\circ} \mathrm{C}, 80 \mathrm{rpm}\right)$ were pelleted by centrifugation $\left(9500 \mathrm{rpm}, 4^{\circ} \mathrm{C}\right.$, $10 \mathrm{~min}$ ). Bacteria washed three times with phosphate buffered saline (PBS, $0.33 \mathrm{M} \mathrm{NaCl}, 3 \mathrm{mM} \mathrm{KCl}, 8.4 \mathrm{mM} \mathrm{Na}_{2} \mathrm{HPO}_{4}, 1.6 \mathrm{mM}$ $\mathrm{KH}_{2} \mathrm{PO}_{4}, \mathrm{pH}$ 7.2), were suspended in PBS. Before the adherence experiments, bacterial cell density was spectrophotometrically adjusted with PBS to $10^{8}$ CFU.mL ${ }^{-1}$ (SINDE; CARBALLO, 2000).

\subsection{Materials and their preparation for attachment experiments}

Stainless steel type 304 (SS), commonly present in the food processing equipment, was donated by Gamelsa (Santiago de Compostela, Spain) in discs of $100.4 \mathrm{~mm}^{2}$. Polytetrafluorethylene (PTFE) (Polypenco Engineering Plastics, Barcelona, Spain), utilized for cutting boards, provided in sheets of $1 \mathrm{~mm}$ in thickness, was cut in cylinders of $6 \mathrm{~mm}$ in diameter, with the result of an area of $75.39 \mathrm{~mm}^{2}$. Rubber type 7S 15 (a blend of styrene-butadiene copolymer and natural rubber), used for milk tubing, supplied in $2 \mathrm{~mm}$ thickness sheets, was cut to obtain pieces of $70.68 \mathrm{~mm}^{2}$.

Pieces of materials were sequentially washed with $1 \%$ (w/v) sodium dodecyl sulphate (SDS, Sigma, Madrid, Spain), distilled water, ethanol (Panreac, Barcelona, Spain), and finally three times with distilled water. Materials were agitated for $10 \mathrm{~min}$ in each liquid. Afterwards, they were air dried (SINDE; CARBALLO, 2000).

\subsection{Bacterial attachment to materials}

Bacterial attachment was determined as described previously by Sinde and Carballo (2000). Three $\mathrm{mL}$ of bacterial suspensions, prepared as specified above, were incubated with pieces of materials for 1 hour at room temperature with $90 \mathrm{rpm}$ constant shaking.

\subsection{Attached bacterial release and count}

After incubation, the materials were rinsed twice with $3 \mathrm{~mL}$ of PBS, immersed in $2 \mathrm{~mL}$ of TSB, and immediately treated ultrasonically (Branson 250, $30 \mathrm{~W}, 20 \mathrm{~s}$ ) in a cooled bath to release the attached bacteria. Ten-fold serial dilutions of TSB in PBS were made and $0.1 \mathrm{~mL}$ portions of each dilution were plated on Salmonella-Shigella Agar (Cultimed) or Listeria Oxford Agar (Biolife, Milano, Italy) plates. After 24-48 hours of incubation at $37^{\circ} \mathrm{C}$, the number of Colony Forming Units (CFU) was counted, and the results were expressed as the $\log _{10}$ of the number of released CFU per $\mathrm{mm}^{2}$. Each adherence experiment was performed three times, and adequate controls (bacterial suspensions without materials) were processed at the same time. This type of experiment was considered our standard of bacterial attachment, so that attached bacteria were treated as indicated in the following sections, and the results obtained in each case were compared with this standard.

\subsection{Sanitizers}

Two commercial sanitizers were obtained from commercial suppliers. According to the declared formulation, the antimicrobial activity of each of the sanitizers was based on the presence of quaternary ammonium compounds (QAC) and alquyldiethylenediamineglycine and di-alquyldiamineethylglycine (DETA).

They were used following the instructions of the respective manufacturers to obtain solutions with the recommended and concentrations twice and four times higher than those values.

\subsection{Treatment of bacteria with heat}

Pieces of materials with attached bacteria, obtained as indicated in the section 2.3 , were submerged in $3 \mathrm{~mL}$ of PBS and treated at $85^{\circ} \mathrm{C}$ for 15 minutes in a thermostatic bath. Then, PBS was removed, and the number of surviving bacteria $\left(\mathrm{CFU} . \mathrm{mm}^{-2}\right)$ was determined as described in section 2.4.

Controls containing $3 \mathrm{~mL}$ of bacterial suspension $\left(10^{8}\right.$ CFU. $\left.\mathrm{mL}^{-1}\right)$ of each strain were processed at the same time in order to check the effect of heat on planktonic bacteria. The 
eventual survival of bacteria was determined by plating $0.1 \mathrm{~mL}$ of the treated suspension onto the specific media indicated in section 2.4.

\subsection{Treatment of bacteria with sanitizers}

Both planktonic and attached bacteria were treated with each sanitizer at the recommended concentrations and with concentrations twice and four times higher than those values.

Planktonic bacteria were challenged with sanitizers by mixing $1.5 \mathrm{~mL}$ of bacterial suspension (containing $10^{8}$ CFU. $\mathrm{mL}^{-1}$ ) of each strain with $1.5 \mathrm{~mL}$ of a solution of each sanitizer with the adequate concentration to obtain the final ones (recommended, twice, or four times higher) in the resulting $3 \mathrm{~mL}$ of mixture. After 15 minutes, ten-fold dilutions were made, and $0.1 \mathrm{~mL}$ portions were plated onto the media already mentioned to obtain the number of CFU.mL $\mathrm{mL}^{-1}$ surviving the treatment.

Pieces of materials with attached bacteria, obtained as explained previously, were treated with $3 \mathrm{~mL}$ of the adequate concentration of each sanitizer for 15 minutes. Then, the materials were washed with PBS ( $3 \mathrm{~mL}$, twice), and the number or surviving bacteria was detected as already explained.

\subsection{Treatment of bacteria with heat and sanitizers}

Planktonic and attached bacteria were treated with sanitizers at the recommended concentrations and heat. The procedure used was the same as that indicated in the previous section but heating at $85^{\circ} \mathrm{C}$ at the same time.

\subsection{Statistical analysis}

Statistical analysis was performed with the SPSS package (SPSS 16.0 for Windows, USA). Comparisons were carried out at $95 \%$ confidence by using ANOVA and a posteriori multiple comparison tests.

\section{Results and discussion}

\subsection{Effect of heat}

None of planktonic Salmonella or L. monocytogenes strains survived the heat treatment, nor did attached Salmonella strains. Most of L. monocytogenes strains attached to the different materials survived the heat treatment (Table 2), although in all cases of survival there was a significative reduction $(\mathrm{P}<0.05)$ of attached bacteria in comparison with the total attached to each material under the standard conditions (Table 1). Our results may confirm previous ones with respect to the survival of attached L. monocytogenes to heat. Frank and Koffi (1990) and Lee and Frank (1991) demonstrated the increased heat resistance of L. monocytogenes attached to glass and stainless steel. It has also been recognized that $L$. monocytogenes is more resistant to heat when tested in foods than when it is suspended in laboratory media (DOYLE et al., 2001). Salmonella resulted more resistant to heat when attached to muscle tissue (HUMPHREY; WILDE; ROWBURY, 1997). Chmielewski and Frank $(2004,2006)$ developed predictive models for probability of heat inactivation of L. monocytogenes biofilms. They proved that high temperatures and times are needed to achieve probabilities of $75 \%$ of total inactivation of bacteria on stainless steel $\left(80^{\circ} \mathrm{C}, 11.7\right.$ minutes) (CHMIELEWSKI; FRANK, 2004) and $95 \%$ on buna-N rubber $\left(76^{\circ} \mathrm{C}, 6\right.$ minutes) (CHMIELEWSKI; FRANK, 2006).

\subsection{Effect of sanitizers}

Table 3 and Table 4 show the effect of different concentrations of sanitizers QAC and DETA, respectively, on planktonic bacteria. As can be observed, L. monocytogenes strains were destroyed with the recommended or double concentration of QAC, while to eradicate planktonic Salmonella quadruple concentration of QAC was needed (Table 3). The concentration recommended by the manufacturer of DETA was ineffective against both types of bacteria in suspension and, only concentrations four times higher than the recommended ones could guarantee the elimination of these bacteria (Table 4). It is generally recognized that to pass the AOAC International Germicidal and Detergent Sanitizer test, a sanitizer should reduce planktonic microbial populations by five or more log cycles after 30 seconds exposure (LINDSAY; VON HOLY, 1999). Our results indicate that, at the recommended concentration, QAC was more effective against planktonic L. monocytogenes cells (which were reduced by at least 5 log cycles) than against planktonic Salmonella cells (which were decreased by 1-2 log cycles). This should not be an unexpected finding since it is generally recognized that at low temperatures quaternary ammonium compounds are less effective against Gram-negative bacteria (ADAMS; MOSS, 2008). DETA was much less effective

Table 1. Numbers (log CFU.mm ${ }^{-2}$ ) of attached bacteria released from the materials under the standard conditions (media \pm standard error).

\begin{tabular}{lccc}
\hline \multirow{2}{*}{\multicolumn{1}{c}{ Strains }} & \multicolumn{3}{c}{ Materials } \\
\cline { 2 - 4 } & SS & PTFE & RUBBER \\
\hline Salmonella ES3 & $3.9 \pm 3.2$ & $4.9 \pm 4.0$ & $4.6 \pm 3.5$ \\
Salmonella ES9 & $4.4 \pm 3.6$ & $4.1 \pm 3.1$ & $4.2 \pm 3.0$ \\
Salmonella ES20 & $4.7 \pm 3.1$ & $4.7 \pm 3.7$ & $4.8 \pm 3.3$ \\
L. monocytogenes ES15 & $5.5 \pm 4.3$ & $5.8 \pm 4.7$ & $5.8 \pm 4.6$ \\
L. monocytogenes ES24 & $5.1 \pm 4.1$ & $5.6 \pm 4.6$ & $5.3 \pm 4.0$ \\
L. monocytogenes ES25 & $5.2 \pm 3.8$ & $5.5 \pm 4.5$ & $5.3 \pm 4.7$ \\
\hline SS. Stainless steel. PTFE. Polytetrafluorethylene. & &
\end{tabular}

Table 2. Survival $\left(\log\right.$ CFU. $\left.\mathrm{mm}^{-2}\right)$ of attached bacteria to heat treatment ( $85^{\circ} \mathrm{C}, 15$ minutes).

\begin{tabular}{lccc}
\hline \multirow{2}{*}{\multicolumn{1}{c}{ Strains }} & \multicolumn{3}{c}{ Materials } \\
\cline { 2 - 4 } & SS & PTFE & RUBBER \\
\hline Salmonella ES3 & - & - & - \\
Salmonella ES9 & - & - & - \\
Salmonella ES20 & - & - & - \\
L. monocytogenes ES15 & - & 1.4 & - \\
L. monocytogenes ES24 & 2.1 & 1.1 & 1.4 \\
L. monocytogenes ES25 & 2.1 & 2.4 & 2.3 \\
\hline
\end{tabular}

-: No survival. SS: Stainless steel. PTFE: Polytetrafluorethylene. 
against both types of suspended cells since a reduction range from 2.8 to the total elimination was achieved, but only when double concentration than recommended by the manufacturer was used.

The reduction in the number of surviving attached bacteria caused by the different concentrations of sanitizers QAC and DETA are presented in Tables 5 and 6 . These results represent the difference between those shown in Table 1 (which indicates the amount of bacteria attached to each material under the standard conditions, i.e. without heat or sanitizer treatment) and the corresponding surviving bacteria after treatment with each sanitizer.

The treatment of attached bacteria with increasing concentrations of sanitizers resulted in statistically significant

Table 3. Reduction ( $\log$ CFU. $\mathrm{mL}^{-1}$ ) of planktonic bacteria $\left(5 \times 10^{7}\right.$ CFU.mL $\left.{ }^{-1}\right)$ caused by the treatment with different concentrations of sanitizer QAC.

\begin{tabular}{lccc}
\hline \multirow{2}{*}{\multicolumn{1}{c}{ Strains }} & \multicolumn{4}{c}{ Concentration of sanitizer QAC } \\
\cline { 2 - 4 } & $\mathrm{R}$ & $2 \mathrm{R}$ & $4 \mathrm{R}$ \\
\hline Salmonella ES3 & 1.4 & 2.9 & - \\
Salmonella ES9 & 1.8 & 3.9 & - \\
Salmonella ES20 & 1.8 & 3.8 & - \\
L. monocytogenes ES15 & - & - & - \\
L. monocytogenes ES24 & 5 & - & - \\
L. monocytogenes ES25 & - & - & - \\
\hline
\end{tabular}

R: Concentration recommended by the manufacturer. 2R: Double Concentration than recommended by the manufacturer. 4R: Quadruple Concentration than recommended by the manufacturer. -: Total elimination.

Table 4. Reduction ( $\log$ CFU. $\mathrm{mL}^{-1}$ ) of planktonic bacteria $\left(5 \times 10^{7}\right.$ CFU. $\left.\mathrm{mL}^{-1}\right)$ caused by the treatment with different concentrations of sanitizer DETA.

\begin{tabular}{lccc}
\hline \multirow{2}{*}{ Strains } & \multicolumn{3}{c}{ Concentration of sanitizer DETA } \\
\cline { 2 - 4 } & $\mathrm{R}$ & $2 \mathrm{R}$ & $4 \mathrm{R}$ \\
\hline Salmonella ES3 & 0.3 & 3.8 & - \\
Salmonella ES9 & 0.7 & - & - \\
Salmonella ES20 & 0.4 & 4.8 & - \\
L. monocytogenes ES15 & 0.7 & 3.7 & - \\
L. monocytogenes ES24 & 0.4 & 2.9 & - \\
L. monocytogenes ES25 & 0.4 & 2.8 & - \\
\hline R: Concentration recommended by the manufacturer. 2R: Double Concentration \\
double than recommended by the manufacturer. 4R: Quadruple Concentration than \\
recommended by the manufacturer. -: Total elimination.
\end{tabular}

$(\mathrm{P}<0.05)$ reduction in the numbers of bacteria detected although sanitizers were less effective on attached bacteria than on suspended ones. Since reductions in viable counts of attached bacteria of barely 1 or $2 \log$ cycles were obtained when the recommended concentrations of disinfectants were used, it could be concluded that attached cells of both bacteria were more resistant to disinfection with both sanitizers than planktonic ones. Other authors showed that increases in sanitizer (ozone, chlorine and hydrogen peroxyde) concentrations were required to destroy biofilm cells of $L$. monocytogenes in comparison with the corresponding planktonic cells (ROBBINS et al., 2005).

Disinfectant containing QAC used at double concentration reduced attached bacteria by $2-5 \log$ cycles and most of the strains of attached bacteria did not survive the treatment with the quadruple concentration than the recommended, irrespective of the surface to which bacteria were adhered. It is generally assumed that quaternary ammonium compounds adhere to food processing surfaces even after rinsing, thus maintaining their antibacterial effect for hours after the disinfection operation (ADAMS; MOSS, 2008). In a previous study (SINDE; CARBALLO, 2000), we have demonstrated that the treatment of food contact surfaces with QAC lowers their hydrophobicity and the subsequent attachment of Salmonella and L. monocytogenes strains. Therefore, the maintained antibacterial effect of quaternary ammonium compounds could be due to the changes they produce in the physicochemical properties of the surfaces on which they are applied. Most strains of attached Salmonella or L. monocytogenes survived the treatment with a concentration four times higher than that recommended for the sanitizer DETA, regardless the attachment surface.

Our results contrast with those of other authors (KRYSINSKI; BROWN; MARCHISELLO, 1992; RONNER; WONG, 1993; ABRISHAMI et al., 1994; BOURION; CERF, 1996; LINDSAY; VON HOLY, 1999; BREMER; MONK; BUTTLER, 2002), who reported that resistance of bacteria to sanitizers was influenced by the type of surface. These discrepancies could be explained, at least in part, by the fact that they challenged different sanitizers, bacterial species, or attachment surfaces. Moreover, in all of aforementioned investigations, mature bacterial biofilms were used instead of fresh attached bacteria, which was the experimental procedure used in our study. It should be emphasized that if cleaning and disinfection measures are adequately applied in the food industry, the formation of mature

Table 5. Reduction $\left(\log\right.$ CFU.mm $\left.m^{-2}\right)$ of attached bacteria caused by the treatment with different concentrations of sanitizer QAC.

\begin{tabular}{|c|c|c|c|c|c|c|c|c|c|}
\hline \multirow{3}{*}{ Strains } & \multicolumn{9}{|c|}{ Materials } \\
\hline & \multicolumn{3}{|c|}{ SS } & \multicolumn{3}{|c|}{ PTFE } & \multicolumn{3}{|c|}{ RUBBER } \\
\hline & $\mathrm{R}$ & $2 \mathrm{R}$ & $4 \mathrm{R}$ & $\mathrm{R}$ & $2 \mathrm{R}$ & $4 \mathrm{R}$ & $\mathrm{R}$ & $2 \mathrm{R}$ & $4 \mathrm{R}$ \\
\hline Salmonella ES3 & 0.6 & 2.4 & 3.0 & 2.3 & 3.3 & 4.2 & 2.1 & 2.7 & - \\
\hline Salmonella ES9 & 1.4 & 3.8 & - & 1.6 & - & - & 0.8 & - & - \\
\hline Salmonella ES20 & 1.3 & 3.9 & - & 1.1 & 3.0 & - & 1.6 & 4.5 & - \\
\hline L. monocytogenes ES15 & 2.5 & 4.3 & - & 2.8 & 4.6 & - & 1.8 & 3.5 & - \\
\hline L. monocytogenes ES24 & 1.3 & 4.8 & - & 1.7 & - & - & 1.8 & 4.7 & - \\
\hline L. monocytogenes ES25 & 2.0 & 3.7 & - & 1.8 & 3.5 & 4.9 & 1.4 & 2.9 & 4.5 \\
\hline
\end{tabular}

R: Concentration recommended by the manufacturer. 2R: Double Concentration than recommended by the manufacturer. 4R: Quadruple Concentration than recommended by the manufacturer. -: Total elimination. SS: Stainless steel. PTFE: Polytetrafluorethylene. 
Table 6. Reduction (log CFU.mm $\mathrm{mm}^{-2}$ ) of attached bacteria caused by the treatment with different concentrations of sanitizer DETA.

\begin{tabular}{|c|c|c|c|c|c|c|c|c|c|}
\hline \multirow{3}{*}{ Strains } & \multicolumn{9}{|c|}{ Materials } \\
\hline & \multicolumn{3}{|c|}{ SS } & \multicolumn{3}{|c|}{ PTFE } & \multicolumn{3}{|c|}{ RUBBER } \\
\hline & $\mathrm{R}$ & $2 \mathrm{R}$ & $4 \mathrm{R}$ & $\mathrm{R}$ & $2 \mathrm{R}$ & $4 \mathrm{R}$ & $\mathrm{R}$ & $2 \mathrm{R}$ & $4 \mathrm{R}$ \\
\hline Salmonella ES3 & 0.8 & 1.9 & 2.6 & 1.6 & 2.8 & 3.3 & 1.7 & 2.6 & 3.2 \\
\hline Salmonella ES9 & 1.7 & 3.4 & - & 1.0 & 3.3 & - & 1.2 & 3.2 & - \\
\hline Salmonella ES20 & 1.2 & 2.6 & 2.9 & 1.2 & 2.4 & 2.8 & 1.4 & 2.9 & 3.7 \\
\hline L. monocytogenes ES15 & 1.3 & 1.8 & 4.1 & 1.7 & 2.2 & 3.6 & 1.5 & 2.1 & 3.9 \\
\hline L. monocytogenes ES24 & 0.9 & 2.9 & 3.4 & 1.2 & 3.0 & 3.9 & 1.0 & 2.5 & 3.3 \\
\hline L. monocytogenes ES25 & 1.4 & 2.0 & 2.9 & 1.4 & 2.1 & 3.7 & 1.2 & 2.0 & 3.8 \\
\hline
\end{tabular}

biofilms should not occur, but the attachment of bacteria would take place anyhow. That is the reason why our experimental design would be more relevant for the food industry.

The overall results indicate that cells of these pathogenic bacteria attached to food processing surfaces would survive the treatment with the recommended concentrations of these commercial sanitizers, thereby these products would be unlikely to avoid the cross-contamination. Goeres et al. (2004) reported the survival of bacteria in other environments, such as a swimming pool laboratory model operating at recommended ranges. On the other hand, our results would corroborate the current idea that standard tests for the evaluation of sanitizers' efficacy should include both planktonic bacteria and their sessile counterparts (SPRINGTHORPE; SATTAR, 2005). Those tests should also be carried out in the presence of food debris and with consortia of bacteria (DEVERE; PURCHASE, 2007).

\subsection{Effect of sanitizers and heat}

Planktonic or attached bacteria could not survive heating at $85^{\circ} \mathrm{C}$ combined with the treatment with the recommended concentrations of sanitizer QAC or DETA. Hence, combining heat treatment with chemical treatment would be useful to improve the disinfection of food industry surfaces without increasing the concentrations of sanitizers. Consistent with the data reported here, Moorman et al. (2005) found that heat stressed Listeria innocua were more sensitive to a quaternary ammonium sanitizer. Laboratory experiments have shown that bacterial exposure to sublethal concentrations of disinfectants may result in acquisition of resistance (LANGSRUD et al., 2003). Given that Salmonella (MARIN; HERNANDIZ; LAINEZ, 2009) as well as L. monocytogenes (GANDHI; CHIKINDAS, 2007) seemed to be able to develop resistance against disinfectants, our approach would also be useful to reduce the opportunities of resistant bacterial strains selection in the food industry. Oh and Marshall (1995) demonstrated the usefulness of combining chemical and physical (monolaurin and heat) treatments to control L. monocytogenes biofilm problems in the food industry. Biofilm extracellular polymeric substances produced by Pseudomonas putida were removed with a hot alkali cleaner (ANTONIOU; FRANK, 2005). The use of ultrasonication together with chlorine or quaternary ammonium-based sanitizers improved the performance of sanitizers on L. monocytogenes biofilms (BERRANG; FRANK; MEINERSMANN, 2008). These and other researchers (JENSEN; LAMMERT, 2003; AMMOR et al.,
2004; RYU; BEUCHAT, 2005) studied biofilms of bacteria. However, the formation of a biofilm starts with the attachment of bacteria to the surface. Sharma, Ryu and Beuchat (2005) found differences in sensibility to disinfectants of Escherichia coli O157:H7 attached to stainless steel or embedded in a biofilm. Sagripanti and Bonifacino (2000) showed that the increased resistance of attached Pseudomonas aeruginosa to treatment with disinfectants precedes biofilm formation. The present study focuses on early attachment rather than on established biofilm. Actually, we have shown that the combination of sanitizers and heat is effective to remove attached bacteria from the surfaces prior to the formation of a biofilm, thus proving the usefulness of this approach for the prevention of the formation of biofilms. In addition, minimizing the attachment of bacteria and formation of biofilm could be advantageous in reducing the early stages of biofouling (BARRIOS et al., 2005). The combination of heat and chemicals for the decontamination of surfaces could provide an additional security in the food industry.

\section{Conclusions}

The results obtained contribute to the awareness of attachment as mechanism of survival of bacteria in the food industry.

They also indicate that the combination of physical and chemical disinfection would be useful to avoid set up of resistant strains and the development of biofilms in the food industry.

The findings of this study should also warn sanitizer manufacturers about the decreased efficacy of sanitizers against attached bacteria. We suggest that instructions for use should be elaborated after testing sanitizers' effectiveness against attached bacteria.

\section{References}

ABRISHAMI, S. H. et al. Bacterial adherence and viability on cutting board surfaces. Journal of Food Safety, v. 14, n. 2, p. 153-172, 1994. http://dx.doi.org/10.1111/j.1745-4565.1994.tb00591.x

ADAMS, M. R.; MOSS, M. O. Food Microbiology. 3. ed. Cambridge: The Royal Society of Chemistry, 2008.

ALI, L.; KHAMBATY, F.; DIACHENKO, G. Investigating the suitability of the Calgary Biofilm Device for assessing the antimicrobial efficacy of new agents. Bioresource Technology, v. 97, n. 15, p. 1887-1893, 2006. PMid:16256346. http://dx.doi.org/10.1016/j. biortech.2005.08.025 
AMMOR, S. et al. Investigation of the selective bactericidal effect of several decontamination solutions on bacterial biofilms including useful, spoilage and/or pathogenic bacteria. Food Microbiology, v. 21, n. 1 , p. 11-17, 2004. http://dx.doi.org/10.1016/S07400020(03)00051-0

ANTONIOU, K.; FRANK, J. F. Removal of Pseudomonas putida biofilm and associated extracellular polymeric substances from stainless steel by alkali cleaning. Journal of Food Protection, v. 68, n. 2, p. 277-281, 2005. PMid:15726969.

BARRIOS, C. A. et al. Incorporating zosteric acid into silicone coatings to achieve its slow release while reducing water bacterial attachment. Colloids and Surfaces B: Biointerfaces, v. 41, n. 2-3, p. 83-93, 2005. PMid:15737532. http://dx.doi.org/10.1016/j.colsurfb.2004.09.009

BELESSI, C.-E. A. et al. Efficiency of different sanitation methods on Listeria monocytogenes biofilms formed under various environmental conditions. International Journal of Food Microbiology, v. 145, p. S46-S52, 2011. PMid:21093085. http:// dx.doi.org/10.1016/j.ijfoodmicro.2010.10.020

BERESFORD, M. R.; ANDREW, P. W.; SHARMA, G. Listeria monocytogenes adheres to many materials found in food processing environments. Journal of Applied Microbiology, v. 90, n. 6, p. 1000-1005, 2001. PMid:11412331. http://dx.doi.org/10.1046/ j.1365-2672.2001.01330.x

BERRANG, M. E.; FRANK, J. F.; MEINERSMANN, R. J. Effect of chemical sanitizers with and without ultrasonication on Listeria monocytogenes as a biofilm within polyvinyl chloride drain pipes. Journal of Food Protection, v. 71, n. 1, p. 66-69, 2008. PMid:18236664.

BOURION, F.; CERF, O. Disinfection efficacy against pure-culture and mixed-population biofilms of Listeria innocua and Pseudomonas aeruginosa on stainless steel, Teflon and rubber. Sciences des Aliments, v. 16, n. 2, p. 151-166, 1996.

BREMER, P. J.; MONK, I.; BUTTLER, R. Inactivation of Listeria monocytogenes/ Flavobacterium spp. biofilms using chlorine: impact of substrate $\mathrm{pH}$, time and concentration. Letters in Applied Microbiology, v. 35, n. 5, p. 321-325, 2002. PMid:12358696. http:// dx.doi.org/10.1046/j.1472-765X.2002.01198.x

CERF, O.; CARPENTIER, B.; SANDERS, P. Tests for determining in-use concentrations of antibiotics and disinfectants are based on entirely different concepts: "Resistance" has different meanings. International Journal of Food Microbiology, v. 136, n. 3, p. 247-254, 2010. PMid:19853944. http://dx.doi.org/10.1016/j. ijfoodmicro.2009.10.002

CHMIELEWSKI, R. A. N.; FRANK, J. F. A predictive model for heat inactivation of Listeria monocytogenes biofilm on stainless steel. Journal of Food Protection, v. 67, n. 12, p. 2712-2718, 2004. PMid:15633676.

CHMIELEWSKI, R. A. N.; FRANK, J. F. A predictive model for heat inactivation of Listeria monocytogenes biofilm on buna-N rubber. LWT Food Science and Technology, v. 39, n. 1, p. 11-19, 2006. http://dx.doi.org/10.1016/j.lwt.2004.10.006

DAWSON, P. et al. Residence time and food contact time effects on transfer of Salmonella Typhimurium from tile, wood and carpet: testing the five second rule. Journal of Applied Microbiology, v. 102, n. 4 , p. $945-953$, 2007. PMid:17381737.

DEVERE, E.; PURCHASE, D. Effectiveness of domestic antibacterial products in decontaminating food contact surfaces. Food Microbiology, v. 24, n. 4, p. 425-430, 2007. PMid:17189769. http:// dx.doi.org/10.1016/j.fm.2006.07.013

DOYLE, M. E. et al. Heat resistance of Listeria monocytogenes. Journal of Food Protection, v. 64, n. 3, p. 410-429, 2001. PMid:11252490.
FRANK, J. F; KOFFI, R. A. Surface-adherent growth of Listeria monocytogenes is associated with increased resistance to surfactant sanitizers and heat. Journal of Food Protection, v. 53, n. 7, p. $550-554,1990$.

GANDHI, M.; CHIKINDAS, M. L. Listeria: A foodborne pathogen that knows how to survive. International Journal of Food Microbiology, v. 113, n. 1, p. 1-15, 2007. PMid:17010463. http:// dx.doi.org/10.1016/j.ijfoodmicro.2006.07.008

GOERES, D. M. et al. Evaluation of efficacy against biofilm and suspended bacteria in a laboratory swimming pool model. Water Research, v. 38, n. 13, p. 3103-3109, 2004. PMid:15261549. http:// dx.doi.org/10.1016/j.watres.2004.04.041

GRAVESEN, A.; LEKKAS, C.; KNØCHEL, S. Surface attachment of Listeria monocytogenes is induced by sublethal concentrations of alcohol at low temperature. Applied and Environmental Microbiology, v. 71, n. 9, p. 5601-5603, 2005. PMid:16151157 PMCid:1214680. http://dx.doi.org/10.1128/AEM.71.9.56015603.2005

HOLAH, J. T. et al. Future techniques for disinfectant efficacy testing. International Biodeterioration \& Biodegradation, v. 41, n. 3-4, p. 273-279, 1998. http://dx.doi.org/10.1016/S0964-8305(98)00018-3

HUMPHREY, T. J.; WILDE, S. J.; ROWBURY, R. J. Heat tolerance of Salmonella typhimurium DT104 isolates attached to muscle tissue. Letters in Applied Microbiology, v. 25, n. 4, p. 265-268, 1997. PMid:9351276. http://dx.doi.org/10.1046/j.1472-765X.1997.00222.x

JENSEN, B.; LAMMERT, L. Biofilm and disinfection in meat processing plants. International Biodeterioration \& Biodegradation, v. 51, n. 4 , p. $265-269,2003$. http://dx.doi.org/10.1016/S09648305(03)00046-5

JOSEPH, B. et al. Biofilm formation by Salmonella spp. on food contact surfaces and their sensitivity to sanitizers. International Journal of Food Microbiology, v. 64, n. 3, p. 367-372, 2001. http://dx.doi. org/10.1016/S0168-1605(00)00466-9

KATHARIOU, S. Listeria monocytogenes virulence and pathogenicity, a food safety perspective. Journal of Food Protection, v. 65, n. 11, p. 1811-1829, 2002. PMid:12430709.

KRYSINSKI, E. P.; BROWN, L. J.; MARCHISELLO, T. J. Effect of cleaners and sanitizers on Listeria monocytogenes attached to product contact surfaces. Journal of Food Protection, v. 55, n. 4, p. 246-251, 1992.

KUSUMANINGRUM, H. D. et al. Survival of foodborne pathogens on stainless steel surfaces and cross-contamination to foods. International Journal of Food Microbiology, v. 85, n. 3, p. 227-236, 2003a. http://dx.doi.org/10.1016/S0168-1605(02)005408

KUSUMANINGRUM, H. D. et al. Tolerance of Salmonella Enteritidis and Staphylococcus aureus to surface cleaning and household bleach. Journal of Food Protection, v. 66, n. 12, p. 2289-2295, 2003 b. PMid:14672226.

LANGSRUD, S. et al. Bacterial disinfectant resistance - a challenge for the food industry. International Biodeterioration \& Biodegradation, v. 51, n. 4, p. 283-290, 2003. http://dx.doi. org/10.1016/S0964-8305(03)00039-8

LEE, S.-H.; FRANK, J. F. Inactivation of surface-adherent Listeria monocytogenes by hypochlorite and heat. Journal of Food Protection, v. 54, n. 1, p. 4-6, 1991.

LINDSAY, D.; VON HOLY, A. Different responses of planktonic and attached Bacillus subtilis and Pseudomonas fluorescens to sanitizer treatment. Journal of Food Protection, v. 62, n. 4, p. 368-379, 1999. PMid:10419210. 
LO FO WONG, D. M. A. et al. Epidemiology and control measures for Salmonella in pigs and pork. Livestock Production Science, v. 76, n. 3, p. 215-222, 2002. http://dx.doi.org/10.1016/S03016226(02)00121-5

MAI, T. L. et al. Attachment of Listeria monocytogenes to an austenitic stainless steel after welding and accelerated corrosion treatments. Journal of Food Protection, v. 69, n. 7, p. 1527-1532, 2006. PMid:16865881.

MARIN, C.; HERNANDIZ, A.; LAINEZ, M. Biofilm development capacity of Salmonella strains isolated in poultry risk factors and their resistance against disinfectants. Poultry Science, v. 88, n. 2, p. 424-431, 2009. PMid:19151358. http://dx.doi.org/10.3382/ ps.2008-00241

MOORMAN, M. et al. Altered sensitivity to a quaternary ammonium sanitizer in stressed Listeria innocua. Journal of Food Protection, v. 68, n. 8, p. 1659-1663, 2005. PMid:21132975.

OH, D.-H.; MARSHALL, D. L. Destruction of Listeria monocytogenes biofilms on stainless steel using monolaurin and heat. Journal of Food Protection, v. 57, n. 3, p. 251-255, 1995.

OLIVEIRA, K. et al. Comparison of the adhesion ability of different Salmonella Enteritidis serotypes to materials used in kitchens. Journal of Food Protection, v. 69, n. 10, p. 2352-2356, 2006. PMid:17066912.

PALMER, J.; FLINT, S.; BROOKS, J. Bacterial cell attachment, the beginning of a biofilm. Journal of Industrial Microbiology \& Biotechnology, v. 34, n. 9, p. 577-588, 2007. PMid:7766065. http:// dx.doi.org/10.1007/s10295-007-0234-4

RAMESH, N. et al. Evaluation of chemical disinfectants for the elimination of Salmonella biofilms from poultry transport containers. Poultry Science, v. 81, n. 6, p. 904-910, 2002. PMid:12079060.

ROBBINS, J. B. et al.Elimination of Listeria monocytogenes biofilms by ozone, chorine, and hydrogen peroxide. Journal of Food Protection, v. 68, n. 3, p. 494-498, 2005. PMid:15771172.

RODRIGUEZ, A.; McLANDSBOROUGH, L. A. Evaluation of transfer of Listeria monocytogenes from stainless steel and high-density polyethylene to bologna and American cheese. Journal of Food Protection, v. 70, n. 3, p. 600-606, 2007. PMid:17388047.
RODRIGUEZ, A.; AUTIO, W. R.; McLANDSBOROUGH, L. A. Effects of inoculation level, material hydration, and stainless steel surface roughness on the transfer of Listeria monocytogenes from inoculated bologna to stainless steel and high-density polyethylene. Journal of Food Protection, v. 70, n. 6, p. 1423-1428, 2007. PMid:17612072.

RONNER, A. B.; WONG, A. C. L. Biofilm development and sanitizer inactivation of Listeria monocytogenes and Salmonella typhimurium on stainless steel and buna-n rubber. Journal of Food Protection, v. 56, n. 9 , p. $740-758,1993$.

RYU, J.-H., BEUCHAT, L. R. Biofilm formation and sporulation by Bacillus cereus on a stainless steel surface and subsequent resistance of vegetative cells and spores to chlorine, chlorine dioxide, and a peroxyacetic acid-based sanitizer. Journal of Food Protection, v. 68, n. 12, p. 2614-2622, 2005. PMid:16355833.

SAGRIPANTI, J. L.; BONIFACINO, A. Resistance of Pseudomonas aeruginosa to liquid disinfectants on contaminated surfaces before formation of biofilms. Journal of AOAC International, v. 83, n. 6, p. 1415-1422, 2000. PMid:11128146.

SHARMA, M.; RYU, J.-H., BEUCHAT, L. R. Inactivation of Escherichia coli O157:H7 in biofilm on stainless steel with an alkaline cleaner and a bacteriophage. Journal of Applied Microbiology, v. 99, n. 3, p. 449-459, 2005. PMid:16108786. http://dx.doi.org/10.1111/j.13652672.2005.02659.x

SILVA, S. et al. Adhesion to and viability of Listeria monocytogenes on food contact surfaces. Journal of Food Protection, v. 71, n. 7, p. 1379-1385, 2008. PMid:18680936.

SINDE, E.; CARBALLO, J. Attachment of Salmonella spp. and Listeria monocytogenes to stainless steel, rubber and polytetrafluorethylene: the influence of free energy and the effect of commercial sanitizer. Food Microbiology, v. 17, n. 4, p. 439-447, 2000. http://dx.doi. org/10.1006/fmic.2000.0339

SPRINGTHORPE, V. S.; SATTAR, S. A. Carrier tests to assess microbicidal activities of chemical disinfectants for use on medical devices and environmental surfaces. Journal of AOAC International, v. 88, n. 1, p. 182-201, 2005. PMid:15759741.

VALERIANO, C. et al. The sanitizing action of essential oil-based solutions against Salmonella enterica serotype Enteritidis S64 biofilm formation on AISI 304 stainless steel. Food Control, v. 25, n. 2, p. $673-677,2012$. 